\title{
“EQUAL RIGHTS FOR ALL CIVILIZED MEN":
}

\author{
ELITE AFRICANS AND THE QUEST FOR "EUROPEAN" \\ LIQUOR IN COLONIAL ZIMBABWE, 1924-1961*
}

SUMmARY: Between 1924 and 1961 elite Africans in Southern Rhodesia (colonial Zimbabwe) waged a protracted political struggle for the right legally to drink "European" liquor, which had been banned to colonized Africans under the Brussels Treaty of 1890 . Refusing to be lumped with the black masses and basing their claim on the notion that there should be "equal rights for all civilized men", elite Africans argued that they had attained a cultural level comparable to that of the dominant European settlers and should therefore be exempt from the liquor ban. This struggle, which ended successfully in 1961, also highlights other important themes in the history of the emergent African elite in Southern Rhodesia, most notably its political tactics and consciousness. The quest for European liquor helped to hone political skills as well, as a number of individuals who participated in it later became important African nationalist leaders.

One of the most important, though not altogether intended, effects of European colonialism in Africa was the emergence of groups of individuals variously called elite, petty bourgeois, or middle class. ${ }^{1}$ These groups, the size, social composition and political significance of which varied from colony to colony depending on the level of economic development and the intensity of missionary educational activity, generally sought to pattern their lives on the specific European model offered by their colonial overlords. Teachers, clerks, preachers, journalists, lawyers, doctors, nurses, business people and other professionals, they yearned for equal citizenship rights - political, social and economic - with the resident colonialists, whether members of the governmental administration or private citizens. Resisted virtually everywhere until at least the post-World War II era, these yearnings were expressed in especially agonizing ways in settler colonies

* I wish to thank Charles Ambler for his comments on an earlier version of this article. I am also thankful to the editorial committee of this journal and its anonymous referees for their fruitful suggestions.

${ }^{1}$ See, for example, J.F.A. Ajayi, Christian Missions in Nigeria, 1841-1891: The Making of a New Elite (Evanston, 1969); Gavin Kitching, Class and Economic Change in Kenya: The Making of an African Petty-Bourgeoisie (New Haven and London, 1980); and Christine Oppong, Middle Class African Marriage: A Family Study of Ghanaian Senior Civil Servants (London, 1981).

International Review of Social History, XXXVII (1992), pp. 376-397 
like Southern Rhodesia (colonial Zimbabwe), where relatively large European communities had been established. ${ }^{2}$ Fearful of the competition and imbued with notions of white racial superiority over the colonized black population, Rhodesian settlers defiantly rejected the demands of elite Africans for parity status, or, to use the popular phrase, "equal rights for all civilized men". ${ }^{3}$

Among the demands of elite Africans most strongly resisted by Southern Rhodesian settler society was their quest, their struggle to obtain legal access to "European" liquor ${ }^{4}$ that is, distilled spirits, lager beer, wine and other commercial-type alcoholic beverages. The British imperial charter that provided the basis for the establishment of the colony in 1890 specifically prohibited the consumption by Africans of these forms of alcohol, ${ }^{5}$ a prohibition that was subsequently reaffirmed in various legislative measures, most notably the Liquor Act of 1930. This prohibition, colonial officials and white settlers maintained, imposed no particular hardship on Africans, who could still drink the traditional maize- (or sorghum) based "kaffir" (roughly "nigger") beer, regarded as both more nutritious and having a lower alcoholic content than European liquor.

Elite Africans, for their part, did necessarily object in principle to the liquor prohibition. Indeed, they seem to have agreed that it was good public policy when applied to the African masses, whose unsophisticated palates and low wages generally insured that they remained satisfied with the traditional brew and did not aspire to the higher status and more expensive European liquor. Elite Africans argued, rather, that as individuals who had attained a level of "civilization" comparable to that of the white settlers they had earned the right in terms of British justice and notions of fairness to be treated equally, and should therefore be exempt from laws prohibiting Africans from purchasing or consuming European liquor. Not all elite Africans, to be sure, subscribed to this view. Many of them, especially preachers and church workers, strongly influenced as they were by their missionary mentors on social issues, supported the racially discriminatory liquor ban as a positive good and opposed attempts to overturn it.

2 On settler colonialism as a generic phenomenon, see Donald Denoon, Settler Capitalism: The Dynamics of Dependent Development in the Southern Hemisphere (Oxford, 1983).

${ }^{3}$ This phrase is generally attributed to Cecil Rhodes, one-time Prime Minister of the Cape Colony, diamond magnate, and the moving spirit behind the establishment of the colonies of Southern and Northern Rhodesia, for whom they were named.

"While rejecting the notion of "European" liquor in the racially exclusive sense that it was used in Southern Rhodesia and elsewhere in colonial Africa, to avoid unnecessary cumbersomeness I have refrained from putting "European" between quotation marks, except in this instance and in the title.

${ }^{5}$ L.H. Gann, A History of Southern Rhodesia: Early Days to 1934 (New York, 1969), p. 83 . 
Still, the advocates of European liquor refused to be deterred. For over three and a half decades, from the mid-1920s to the early 1960s, they waged a protracted struggle for the right legally to drink European liquor. They struggled not so much for mere access to European liquor, which could easily be obtained on the black market, but rather to remove the stigma that the ban is considered to have placed on those Africans who had risen to a "higher level" and who consequently deserved, and demanded, equality with the whites in all spheres of society. It was only in 1957, however, that the liquor prohibition was partially lifted with an easing of the restrictions on light alcoholic beverages, and it took an additional four years before they were removed entirely.

Investigation of the quest of elite Africans for legal access to European liquor shows how a minority of relatively privileged Africans in a settler colonial society challenged a particular set of racist laws and practices and attempted to assert their claim to equality with the white settlers, albeit to the exclusion of the colonized majority. It also brings into sharp relief a number of important themes in Southern Rhodesian history. To begin with, the manner in which the proponents (and opponents) of European liquor sought to attain their objectives, notably through petitions, deputations, resolutions and letters to the editor, typified the modes of struggle employed by Africans in redressing grievances during most of the period under consideration. Furthermore, this investigation provides valuable insight into the political consciousness of elite Africans, especially their desire to both detach themselves socially and culturally from the African masses and make common cause with the white settlers by forging a class alliance based on a "culture", as opposed to a color, bar. The settlers' rejection of this formula, and more to the point, elite African acceptance of this reality, goes a long way toward explaining the rise of African nationalism in Southern Rhodesia in the late 1950s and early 1960s.

Europeans had not always sought to deny Africans access to their liquor, and a prohibitionist movement directed specifically against Africans only emerged in the second half of the nineteenth century. Liquor, in fact, had been an important commodity in the development of direct, sustained commercial relations between Africa and Europe, beginning in the fifteenth century. ${ }^{6}$ Thus, while disagreeing on its relative quantitative importance in the overall Euro-African commerce, ${ }^{7}$ historians agree that liquor was a "constant" and "decisive" factor in the infamous Atlantic slave

${ }^{6}$ J.W. Blake, European Beginnings in West Africa, 1454-1578 (London, 1937).

7 A.G. Hopkins, An Economic History of West Africa (New York, 1973), pp. 111, 129; Philip D. Curtin, Economic Change in Precolonial Africa: Senegambia in the Era of the Slave Trade (Madison, 1975), pp. 318, 326; Joseph C. Miller, Way of Death: Merchant Capital and the Angolan Slave Trade, 1730-1830 (Madison, 1988), pp. 83-84. 
trade. ${ }^{8}$ With the rise in the nineteenth century of anti-liquor sentiments in Britain and elsewhere in the North Atlantic world, ${ }^{9}$ however, reformers of various stripes - prohibitionists, antislavery advocates, missionaries, and proponents of "legitimate" commerce - all came to view the African liquor trade as particularly odious and objectionable. This trade, they argued, was a major contributor to the physical and moral degeneration of Africans, and strongly urged its suppression..$^{10}$ In response, the European imperialist powers, eager to bolster the alleged humanitarian imperative of their colonial ventures, agreed in the Brussels Treaty of 1890 to ban the sale of liquor to Africans. ${ }^{11}$

The anti-liquor sentiments prevalent in Europe in the late nineteenth and early twentieth centuries were replicated among the predominantly British settlers of Southern Rhodesia, some of whom formed temperance societies and even attempted unsuccessfully to introduce prohibition for the white population. In 1921, for instance, a member of the all-white Legislative Council introduced a motion, which caused considerable debate, to hold a referendum on prohibition among the white settlers. But the white advocates of comprehensive prohibition proposed to exclude "kaffir" beer from the ban, as they believed that African drinking habits were too deeply ingrained to be changed any time soon. "The customs of the natives", one of them averred, "their systems of agriculture, their marriages, the deaths of the people, were all connected and mixed up with the system of beer drinking; everything that they did was either followed or preceded by a beer

K. Onwuka Dike,Trade and Politics in the Niger Delta, 1830-1885: An Introduction to the Economic and Political History of Nigeria (Oxford, 1956), pp. 105-106; Walter Rodney, A History of the Upper Guinea Coast, 1545-1800 (Oxford, 1970), pp. 177-181. See also Leroy Vail and Landeg White, Capitalism and Colonialism in Mozambique: $A$ Study of the Quelimane District (Minneapolis, 1980), pp. 126-129.

"See, for example. Brian Harrison, Drink and the Victorians: The Temperance Question in England, 1815-1872 (London, 1971); Lilian Lewis Shiman, Crusade against Drink in Victorian England (New York, 1988); and James S. Roberts, Drink, Temperance and the Working Class in Nineteenth-Century Germany (Boston, 1984).

${ }^{10}$ Lynn Pan, Alcohol in Colonial Africa (Helsinki, 1975); A Olorunfemi, "The Liquor Traffic Dilemma in British West Africa: The Southern Nigerian Example, 1895-1918", International Journal of African Historical Studies, 17 (1984), pp. 229-241; Raymond E. Dumett, "The Social Impact of the European Liquor Trade on the Akan of Ghana (Gold Coast and Asante. 1875-1910)", Journal of Interdisciplinary History, 5 (1974), pp. 69101. The anthropological literature, with its emphasis on the "functional" role of indigenous alcoholic beverages in precolonial African societies, as opposed to the "dysfunctional" influence of Western-type distilled liquor, tends to support the humanitarian argument. For a critique of the functionalist approach, see Charles H. Ambler, "Alcohol and Disorder in Precolonial Africa", Working Papers in African Studies, No. 126 (African Studies Center, Boston University, 1987).

1 Pan, Alcohol in Colonial Africa, pp. 31-40. 
drink." 12 Insofar as this assertion gives the impression that African life revolved around beer drinking it is, of course, a gross exaggeration. Nevertheless, beer was an important economic, social and cultural factor in the precolonial societies of Zimbabwe, and in Bantu-speaking southern Africa as a whole. ${ }^{13}$

The vociferous anti-liquor minority notwithstanding, alcohol also played a major role in Southern Rhodesian white settler society, as evidenced by the popularity to the "sundowner", that uniquely Rhodesian drinking spree. But, whatever their views on drinking generally, the vast majority of whites believed that the prohibition of European liquor to Africans should be maintained. Some did so in order to emphasize the status distinction between themselves and the "natives", while others asserted that granting Africans access to European liquor would result in economic and social problems, including the withdrawal of labor, uncontrollable drunkenness, and attacks on white women, the notorious "black peril" argument. ${ }^{14}$ "I am totally in favour of the entire prohibition of alcoholic liquors to natives", one Southern Rhodesian Assistant Native Commissioner informed the region-wide South African Native Affairs Commission of 1903-1905:

I consider that if these natives had access to spirituous liquors they would become thoroughly demoralized. That both European and native persons lives would be endangered, that no woman would be safe, they would become undesirable persons to have in the employ of private persons, they would become absolutely untrustworthy once they had acquired the taste for alcohol, and would eventually sink to a very low [level] and become a very degraded race of people. ${ }^{15}$

Other settlers adopted a more paternalistic attitude, supporting the ban on European liquor not merely for ulterior motives but for the "natives" own

${ }^{12}$ Debates in the Legislative Council during the Second Session of the Seventh Council, 25th April to 27th May, 1921, cols 301-330, 361-405 (quotation on col. 374).

${ }_{13}$ Harry F. Walcott, The African Beer Gardens of Bulawayo: Integrated Drinking in a Segregated Society (New Brunswick, N.J., 1974), pp. 68-79; Eileen Jensen Krige, "The Social Significance of Beer among the Balobedu", Bantu Studies, 6 (1932), pp. 343-357. See also Walter H. Sangree, "The Social Function of Beer Drinking in Bantu Tiriki", in David J. Pittman and Charles R. Snyder (eds), Society, Culture, and Drinking Patterns (New York and London, 1962), pp. 6-21.

i4 "Black peril" scares seem to have been a conditioned reflex on the part of white settlers in southern Africa. See Norman Etherington, "Natal's Black Rape Scare of the 1870s", Journal of Southern African Studies, 15 (1988), pp. 36-53; Charles van Onselen, Studies in the Social and Economic History of the Witwatersrand, 1886-1914: New Ninevah, vol. 2 (London, 1982), pp. 1-73; and John Pape, "Black and White: The 'Perils of Sex' in Colonial Zimbabwe", Journal of Southern African Studies, 16 (1990), pp. $699-720$.

${ }_{15}$ National Archives of Zimbabwe (hereafter NAZ), N3/6/3: South African Native Affairs Commission: Evidence of Asst. Native Commissioner, M'Toko, p. 129. 
good. Thus, another official, speaking from "the native point of view", announced to the commission that he was "strongly in favour of prohibition [. . .] purely to keep the native from becoming a low brute which he would soon become if he were allowed to get drink". ${ }^{16}$ Whatever the motivation, this conclusion was heartily endorsed in the commission's final report, which recommended that "the penalties attaching throughout South[ern] Africa to conviction for supply of liquor to prohibited persons should be such as to leave no doubt of the serious light in which the offence is regarded". ${ }^{17}$

Subsequent offical reports also concluded that Africans should strictly be kept away from European liquor. An investigation committee of 1910-1911, for example, found that "On the question of the supply to natives of intoxicating liquor, there was no difference of opinion [among white witnesses]. The necessity for total prohibition was urged without a dissentient voice." 18 This was not entirely so, for there was the occasional white dissenter, later if not then. Thus, in 1930 the Rev. G.H.B. Sketchley of the Wesleyan Methodist Church suggested that, as a means of discouraging the illicit brewing of "kaffir" beer, the municipal beerhalls should cultivate "a taste in natives for a better beer which is stronger than the 3 per cent allowed by law and perhaps even in European liquor". ${ }^{19}$ But this was definitely a minority view within Rhodesian settler society. As late as 1941 the bulk of the leadership of the "socialist" Rhodesia Labour Party remained firmly opposed to the idea that Africans, even the most "civilized" ones, should be allowed to drink European liquor. It was, the party's parliamentary leader declared, "not in their interests that this should be done". ${ }^{20}$

African advocates of European liquor, on the other hand, believed that they knew better than white settlers and government officials what was in their own best interests. Consequently, in 1924, in what apparently was the first such move by an organized body, the Southern Rhodesia Native Association, then one of the leading African protest movements in the colony, petitioned the government to open special bars to sell brandy to elite Africans. ${ }^{21}$ This request was followed up five years later by a similar one from the Rhodesia Bantu Voters' Association, another petty-bourgeois protest movement and sometime rival of the Rhodesia Native Associ-

${ }^{16}$ Ibid.: Evidence of Native Commissioner, Umtali and Inyanga, p. 160.

${ }_{17}$ South African Native Affairs Commission Report, 1903-05 (Cape Town, 1905), p. 75.

${ }_{18}$ Report of the Native Affairs Committee of Enquiry, 1910-11 (Salisbury, 1911), p. 19.

${ }^{19} \mathrm{NAZ}, \mathrm{S235/477}$ : Notes on Evidence of Enquiry into Bulawayo Location, 1930, p. 9. The " 3 per cent allowed by law" refers to the alcoholic content of the traditional-type beer sold in the city-run beerhalls.

${ }^{20}$ Bantu Mirror (Bulawayo, hereafter BM), 28 June 1941.

21 NAZ, S138/22: Chief Native Commissioner[?] to Sec. to Premier, 27 Sep 1924. 
ation, which urged the government to grant African voters, who at that time numbered less than one hundred, "ample rights" to purchase and consume European liquor. ${ }^{22}$

While little evidence for this earlier period is available on this point, it appears that these requests were aimed at giving legal recognition to a de facto reality rather than establishing a right as a precedent to exercising it. Africans, in short, illicitly had been drinking European liquor all along. "With regard to the native population", the Colonial Secretary noted during the debate over the Liquor Bill of 1930, "there is no doubt there is a certain amount of illicit liquor sold", apparently referring to European alcohol. ${ }^{23}$ In any case, given the relatively high cost of European liquor, almost all of which during this period was imported and heavily taxed, only a small number of Africans were in a position to purchase it on the black market.

It is not accidental that elite Africans began campaigning for legal access to European liquor in the 1920s. The movements that initiated the campaign, notably the Rhodesia Native Association and Bantu Voters' Association, had been founded in the early years of the decade as vehicles for championing the aspirations of the emergent African petty bourgeoisie. ${ }^{24}$ In addition to liquor, the associations also concerned themselves with such predominantly African petty-bourgeois issues as maintaining the "colorblind" property and literacy qualifying franchise, ${ }^{25}$ increasing the amount of land available to Africans for acquisition on a freehold basis, and enlarging educational opportunities, the most important avenue of upward social mobility.

The European liquor issue, then, was part of a larger attempt to articulate a political and social agenda encompassing the strivings of elite Africans, including their desire to draw a sharp distinction between themselves and the peasants and workers from among whose ranks they had emerged. As early as 1925, in fact, the Bantu Voters' Association had called upon the authorities to "consider seriously the increasing evil of drunkenness" in the municipal beerhalls. ${ }^{26}$ The proletarian character and general disrespectability of the beerhalls, as this champion of elite African interests saw it, disqualified them as venues for socialization. It thus comes as no surprise

22 NAZ, S482/709/39, vol. 1: Pres., Rhod. Bantu Voters' Assoc. to Prime Min. (Min. of Native Affairs), 22 May 1929.

${ }_{23}$ Debates of the Legislative Assembly, vol. 9 (Salisbury, 1930), col. 428.

${ }^{24}$ T.O. Ranger, The African Voice in Southern Rhodesia, 1898-1930 (Evanston, 1970).

25 African voters comprised only a small fraction of the electorate. Unlike South Africa, with its whites-only "herrenvolk democracy", the franchise in Southern Rhodesia was based on income (or property) and literacy qualifications. By restricting African social mobility and continually raising the income qualifications, however, Southern Rhodesia guaranteed white supremacy just as effectively as South Africa.

26 NAZ, S138/22: Rhod. Bantu Voters' Assoc.: Annual Conference. 13 July 1925. 
that four years later the Bantu Voters' Association would demand that African voters to be given "ample rights" to purchase European liquor. Among other things, the struggle for European liquor was an attempt on the part of elite Africans to obtain spatial separation from the African working people, who constituted the bulk of the beerhalls' clientele and were consequently held responsible for the drunkenness and other "evils" they were said to promote.

Established in the two major cities of Bulawayo and Salisbury in 1913 and 1915 respectively (later in the smaller towns), the municipal beerhalls initially were conceived as instruments of social control, though they later became an important source of city revenue as well, especially for "native welfare". Primarily, though, they were instituted in an effort to prevent, or at least discourage, workers from patronizing illicit beer brewers within the urban areas or from traveling into the surrounding countryside in search of drink. By controlling the opening hours of the beerhalls and determining the alcoholic content (first three and later four percent) of the beer they dispensed, both employers and the state hoped to mitigate the effects of drinking on production and reduce the possibility of social conflict. As the Attorney General stated in 1917, on Sundays domestic servants (the vast majority of whom were men) and other workers in Salisbury "were apt to wander far afield [. . .] to obtain beer, and there were all sorts of places within the vicinity of the commonage where they could go, and in many cases they came home helplessly drunk - when they came home at all". The beerhalls were aimed at rectifying this unsatisfactory state of affairs, and employers "hoped and believed that the sale of beer [there] was controlled, and that when the boys were sent home they were in a condition to reach home". ${ }^{27}$

Many workers, however, refused to take their drinks at the beerhalls, preferring instead to patronize the illicit brewers, most of whom were women popularly known as "skokiaan queens". ${ }^{28}$ Even so, the beerhalls quickly developed a reputation as workers' havens, characterized by what many elite Africans saw as so much drunkenness, rowdiness and hooliganism. Thus, in their quest for respectability and recognition by white society, certain members of the emergent African petty bourgeoisie, dissatisfied with both the beerhalls and the traditional-type beer they sold, sought to

${ }^{27}$ Debates in the Legislative Council during the Fourth Session of the Sixth Council, 11th April to 3rd May, 1917, col. 155. The "boys" in question were adult men, which was how most white settlers in Southern Rhodesia referred to all African males.

28 The "skokiaan queens", some of whom doubled as prostitutes, were very effective in competing with the municipal beerhalls, thereby incurring the wrath of officialdom. For a discussion of illicit female brewers in the mining districts, see Charles van Onselen, Chibaro: African Mine Labour in Southern Rhodesia, 1900-1933 (London, 1976), pp. $166-172$. 
distinguish themselves from the masses in terms of the kind of liquor they drank as well as where they drank it. ${ }^{29}$

While they fought for its legalization, elite Africans continued to drink European alcohol, observing the liquor prohibition mostly in the breach. "Where the supply of liquor to Natives has been prohibited", the South African Native Affairs Commission of 1903-1905 had noted ruefully, "difficulty has arisen, as was to be expected, in the detection of contraventions of the law. The Natives are unwilling to give information against the dealers from whom they purchase [. . .] [liquor] illicitly." ${ }^{30}$ In Southern Rhodesia, as elsewhere in region where European liquor was prohibited to Africans, there was no shortage of such dealers willing to supply illicit drinkers with all the booze they could afford. ${ }^{31}$

Government officials in Southern Rhodesia, joined by other observers, tended to blame members of the coloured (mixed-race) community for the traffic in European liquor ${ }^{32}$ And, in fact, some coloureds, especially truck drivers, given their mobility and consequent opportunity to exploit commercial openings, were involved in this illicit trade. On the other hand, the coloureds - widely considered an embarrassment by both whites and blacks, from whom they were separated socially and spatially - were made to bear far more of the responsibility for liquor trafficking that the evidence seems to warrant. They were not the only, or necessarily the most important, source of the European liquor obtained by Africans. In the first place, the coloureds were also denied legal access to European liquor until 1938, when the Liquor Law was amended to give them "equality" with the Asians

29 The elite African demand for separate drinking facilities received as much attention from the authorities as the one for European liquor. Thus, renewing an "old request", in 1950 "progressive Africans" in Bulawayo became "indignant at the rough conditions and behaviour of their fellow Africans at the Beer Hall", demanding that "better conditions be created by recognition of the City Council of the middle class African". These "progressive" and "middle class" Africans wanted a private club, run on beerhall profits and controlled by a committee consisting of themselves, with membership restricted to "only those Africans who are prepared to be orderly and [to] behave themselves as provided by the rules of the Club". See $B M, 14$ Oct 1950.

${ }_{30}$ South African Native Affairs Commission Report, p. 75.

${ }^{31}$ In what would later become the Union of South Africa, the sale of liquor to Africans was first banned in 1896 in the gold-producing Transvaal Republic. This, however, led to the development of a highly lucrative illicit liquor business. See Charles van Onselen, Studies in the Social and Economic History of the Witwatersrand, 1886-1914: New Babylon, vol. 1 (London 1982), pp. 44-102; and The Illicit Liquor Problem on the Witwatersrand: Report of Unofficial Commission Appointed by the South African Temperance Alliance and the South African Institute of Race Relations (May 18th, 1935).

32 NAZ, S482/709/39, vol. 1: Town Clerk, Bulawayo to Sec. to Premier, 23 Jan 1934; BM, 3 July 1954, 29 Jan 1955; Lawrence Vambe, From Rhodesia to Zimbabwe (Pittsburgh, 1976), pp. 216-217. 
(mainly Indians) ${ }^{33}$ notably, the right to purchase liquor by permit. ${ }^{34}$

Coloureds were thus unlikely to have been involved in trafficking to any significant extent before obtaining legal access to European liquor themselves. Indeed, up to that point the coloureds also bought liquor on the black market. "[T]here is a regular trade going on between certain people who purchase [liquor] and who resell it to the unfortunate coloured people", one member of the Legislative Assembly pointed out during the debate to lift the ban on coloureds. ${ }^{35}$ The "certain people" in question were, of course, white, and they also supplied African drinkers. Nor did coloureds suddenly begin to dominate the illicit liquor business after 1938 . Twenty years later the report of a parliamentary select committee on the supply of liquor to "non-Europeans" concluded that they had been singled out unfairly for their role in liquor trafficking. As the chairman of the committee explained:

Considerable evidence was laid before us on this problem, and attempts were made in certain quarters to pin responsibility for this illicit traffic on one particular section of the community. I refer to the Eurafrican and Coloured community. I wish to place on record that the Police statistics did not bear that out, and responsibility for a lot of this illicit traffic rests on European. It rests on all sections of the community, as much on the European as on any other section. ${ }^{36}$

Responsibility for supplying African drinkers with European liquor also rested on African dealers, who mostly obtained their supplies through theft

${ }^{33}$ Asians had been exempt from the prohibition all along, though they had to obtain a permit in order to purchase liquor.

${ }^{34}$ An attempt two years earlier to give coloureds the right to purchase European liquor was unsuccessful, with opponents citing widespread drunkenness among South Africa's coloured population and expressing fear that Southern Rhodesian coloureds would suffer the same fate if permitted to drink.

In 1938, in its successful petition to the Legislative Council urging repeal of the liquor prohibition as it applied to coloureds, the Coloured Community Service League drew a sharp distinction between coloureds and Africans. The former, unlike the latter, the petition asserted, could not "be described as being in the barbaric stage to warrant such a stigma being placed upon them". Thus coloureds, like elite Africans, regarded legal access to European liquor as an important status advancement and public recognition of their place among the colony's "civilized" community. See Debates of the Legislative Assembly, vol. 16 (Salisbury, n.d.), cols 3008-3158; Debates of the Legislative Assembly, vol. 18 (Salisbury, n.d.), col. 1673.

${ }^{35}$ Debates of the Legislative Assembly, vol. 18, col. 1488.

${ }^{36}$ Debates of the Legislative Assembly (unrevised), 23rd April, 1959, no. 60 (Salisbury, 1959), col. 3434. See also Legislative Assembly. First Report of the Select Committee on Supply of Liquor to Non-Europeans (11th March, 1959), and Legislative Assembly. Second Report of the Select Committee on Supply of Liquor to Non-Europeans (16th April, 1959). 
caused by what the select committee chairman called "careless administration in bottle stores and other places where liquor is kept, resulting in enormous quantities of liquor finding its way unto the black market". ${ }^{37}$ African traffickers, in fact, were probably an important source of illicit European liquor all along, and they certainly became so by the 1950s. Another legislator involved in the investigation of the illicit liquor business asserted in 1959 that the evidence showed "that the largest source of illicit supply of spirits was through the traffic by pilfering from bottle stores by natives for re-sale to Natives." ${ }^{38}$ The prominence of Africans in the illicit liquor trade was due to one overriding factor, namely, their lower prices. African dealers, who generally had no capital outlay to recoup, simply undersold all competitors. They were, illicit drinker Lawrence Vambe explains, "anxious to be rid" of the stolen goods as quickly as possible. ${ }^{39}$ Asians, additionally, were sometimes accused of selling European liquor to Africans. ${ }^{40}$

A few illicit African drinkers would occasionally be caught and prosecuted. In 1940, for instance, B.J. Mnyanda, then the chairman of the African section of the Bulawayo African Welfare Society, a group charged with organizing "safe" leisure for urban residents, and one of the most prominent blacks in the colony, was arrested on charges of possessing two bottles of beer. A subsequent search of his house also turned up a bottle of brandy. After entering guilty pleas, both Mnyanda and his African supplier were each fined $f 5 .^{41}$ By the mid-1950s, conviction for possession of European liquor usually carried a fine of up to $£ 10$. Traffickers, on the other hand, could be fined up to $£ 200$ or imprisoned for up to a year. Generally speaking, though, African drinkers were undeterred, for the chances of being apprehended were quite slim. As far as enforcement of the liquor prohibition was concerned, the arm of the law was neither swift nor sure. Indeed, in an implicit recognition of impotence, the authorities apparently made only a minimal effort to bring violators of the liquor ban to justice, particularly in the post-World War II period.

The ranks of such violators certainly increased during this period, as the consumption of European liquor became a distinguishing feature of a growing segment of the African petty bourgeoisie, which more and more came to assume its own unique identity. The enormous expansion of Southern Rhodesian secondary industry during the war, accompanied by unprecedented government expenditure on African education, albeit from

37 Debates of the Legislative Assembly, 23rd April, 1959, col. 3434.

38 Ibid., col. 3446.

${ }^{39}$ Vambe, From Rhodesia to Zimbabwe, p. 217.

* NAZ, S482/709/39, vol. 1: Town Clerk, Bulawayo to Sec. to Premier, 23 Jan 1934.

${ }^{4} B M, 28$ Dec 1940. See also BM, 23 Jan 1954, 10 Sep 1955. 
a low base, opened up new employment opportunities for elite Africans, especially in the urban centers. ${ }^{42}$ These individuals, many of whom were known for their partiality to ballroom dancing and good timing generally, also acquired a strong taste for European liquor.

Vambe, an astute journalist and new member of the expanding petty bourgeoisie, observes that during the postwar years European liquor increased in importance as a high status drink, becoming "the very symbol of economic and cultural superiority". African businessmen and professionals in Salisbury, he continues, "wanted regular supplies, especially at Christmas, Easter and other public holidays, and private celebrations. Even the dead were propitiated in gin, whisky, brandy and rum." European liquor, moreover, had a quick intoxicating effect, and it served as a bait for women:

Distilled and clarified liquor had many advantages over the local native beer. It was clean and one got tipsy quickly on it. It attracted many friends, especially women. Indeed, a man known to be able to entertain well on European liquor easily attracted vana vaka chena, the beautiful, interesting girls employed in the domestic service of white Salisbury. ${ }^{43}$

The growing demand for European liquor resulted in an expansion of the illegal shebeen business. The primary outlet for distribution of the illicit brew made by the skokiaan queens, the shebeen, even more so than the beerhall, was despised by elite Africans. Eager to cash in on an expanding market, however, some of the more prosperous skokiaan queens, joined by a growing number of "kings", branched out in the postwar years by establishing trendier, more attractive shebeens, expressly to serve European liquor to elite African drinkers.

While able to obtain all the European alcohol they desired, elite African drinkers resented the socially-levelling effect of the liquor prohibition, objecting that it failed to distinguish between them and the masses. During the Depression years of the 1930s, the Rhodesia Native Association and the Bantu Voters' Association, which had spearheaded the quest for European liquor, either became inactive or disappeared from the political scene altogether.$^{44}$ In their place came the Southern Rhodesia African Missionary Conference, a clerical-dominated group that promptly removed the liquor issue from the political agenda. As movements dominated by laymen

\footnotetext{
12 Ian Phimister, An Economic and Social History of Zimbabwe, 1890-1948: Capital Accumulation and Class Struggle (London and New York, 1988), pp. 219-296; Michael Oliver West, "African Middle-Class Formation in Colonial Zimbabwe, 1890-1965" (Ph.D., Harvard University, 1990), pp. 45-65.

${ }^{43}$ Vambe, From Rhodesia to Zimbabwe, pp. 216-218 (long quotation on p. 218).

"West, "African Middle-Class Formation", pp. 338-345.
} 
reasserted control over African political life in the postwar years ${ }^{45}$ however, the demand for legal access to European liquor once more became an issue of importance, one about which representations were made to the authorities.

Consequently, in 1946, the African Voters' League, a group representing enfranchised Africans in Salisbury and a few smaller urban centers, called upon the government to amend the law to give African voters the right to purchase and consume European liquor. In their letter to the Prime Minister (Minister of Native Affairs), the members of the Voters' League explained that on this, as on other issues, "African voters feel that there should be a clear distinction between those Africans who have secured registration as voters and those who are not registered" ${ }^{46}$ Voters' League member Charles Mzingeli, variously a trade unionist, businessman and political leader, vigorously supported the view that "African voters in Southern Rhodesia should be given the privilege of possessing European liquor". ${ }^{47}$ In sum, the Voters' League and like-minded groups and individuals argued, the social demarcation separating elite Africans from the other "civilized" sectors of society and lumping them together with the "raw natives" should be broken down. "I cannot but repeat that it is more than a mere bottle of liquor that we demand", one anguished advocate of European alcohol explained. "It is justice we want so that the attitude may change of people who always consider Africans to be their inferiors."48

Elite Africans, furthermore, considered themselves respectable and lawabiding citizens and consequently took great umbrage at the fact that the otherwise harmless act of having a drink left them open to criminal prosecution. "Self-respecting Africans", asserted M.M. Hove, one of two Southern Rhodesian African representatives in the parliament of the Federation of Rhodesia and Nyasaland, should be granted the right "to have their drink without having to expose themselves to the unbecoming conditions to

\footnotetext{
45 Between 1943 and 1948 the Bantu Congress, one of the leading African political movements during and after World War II, was under the presidency of the Rev. T.D. Samkange, a Wesleyan Methodist minister and noted opponent of liquor in all its forms. However, unlike the African Missionary Conference, which Samkange also served as secretary for a long time, the Bantu Congress was not dominated by clerics. Most of the other officers and the vast majority of its members were lay people. See Terence Ranger, "The Bantu National Congress of Southern Rhodesia, 1943 to 1948: A Revisionist Interpretation" (unpub. paper, African Research Seminar, St. Anthony's College, Oxford, 12 November 1991). On Samkange's attitude toward liquor, see NAZ, S235/ 477: Notes on Evidence of Enquiry into Bulawayo Location, 1930, p. 63.

${ }^{46}$ NAZ, S482/717/39: Pres., Af. Voters' League to Prime Min. (Min. of Native Affairs), 2 Dec 1946.

${ }^{47}$ NAZ, S517: P/Det. Criminal Investigation Dept. to Provincial Criminal Investigation Dept., Mashonaland, 31 Aug 1949.

t* $B M, 2$ June 1956.
} 
which they are subjected at present" ${ }^{49}$ Solomon Dzwittie, a Salisbury social worker and journalist, agreed, arguing that the government should become "realistic and face up to the fact that the [Liquor] Act has not succeeded and never will succeed in stopping Africans from drinking European liquors". All it did, rather, was to promote criminal activity by forcing "otherwise well behaved citizens to flout the law of the country" ${ }^{50}$ Legalization of European liquor, these Africans and their supporters maintained, would at once result in an instant reduction of the crime rate, both by legitimating drinking and, what was more important, destroy the illegal liquor trade. ${ }^{51}$

As was indicated at the outset, however, the African petty bourgeoisie did not speak with one voice on the liquor issue. Responding to the persistent agitation of those on the other side, elite African opponents of European liquor came out strongly against legalization in the post-World War II era. Prime Minister Garfield Todd, himself a former missionary who had "no estimation of alcohol as a civilising agent", reported in 1956 that while a "number" of Africans desired removal of the liquor prohibition, "thousands" more had signed petitions opposing such a move. ${ }^{52}$ An unscientific poll conducted in Bulawayo, one evidently weighted heavily in favor of the more "articulate" Africans, also showed majority support for maintaining the discriminatory liquor law. ${ }^{53}$ The opponents argued that the consumption of European liquor was no evidence of civilization, that its legalization would undermine the social and moral structure of the family, and that, in any case, there were far more important issues with which Africans should concern themselves.

A typical exponent of the anti-European liquor position, the Rev. $\mathrm{H}$. Kachidza, a Wesleyan Methodist minister and strict prohibitionist, posed the question, "Is drinking European liquor a sign of civilisation?" His answer was that he was "not prepared to sink with the white man in all his vices", as alcohol "is Satan's secret weapon to destroy man [. . .] [The] drinking of liquor is not a sign of civilisation. It is a curse. " 54 In a similar vein, another opponent of European liquor demanded to know if "any race [had] been advanced on the road towards civilisation by beer?" Arguing that alcohol "makes us sink financially, morally, physically and even as a race", he urged Africans to "fight against any attempt to alter the present liquor law". ${ }^{55}$ Others opposed the campaign for the legalization of European liquor not so much on moral as on practical grounds, believing that the

49 BM, 27 Mar 1954.

51) Concord (Salisbury), May 1955, p. 20.

51 See, for example, the $B M$ editorials of 10 Apr 1948 and 30 Mar 1957.

52 BM, 1 Dec 1956.

${ }_{53} B M, 23$ Feb 1957.

54 $B M, 5$ May 1956.

$55 B, 23$ June 1956. 
effort expended on fighting prohibition could be more productively channeled into redressing more important grievances. While not necessarily committed prohibitionists, these individuals took the position that liquor was a "secondary" issue, and that the liquor prohibition, though racially discriminatory, was "the least painful of the many political diseases with which the Africans are inflicted" ${ }^{56}$ One trade unionist who came out against legalization argued that it would encourage individuals earning low wages to buy European beer, instead of the cheaper and more nutritious traditional brew. ${ }^{57}$ Fearing that legalization would result in a greater incidence of broken homes and juvenile delinquency, some supported the existing law as a being in the best interests of the African community. ${ }^{58}$ Indeed, in a throwback to an earlier period, some prohibitionists, contending that the law was more "advanced" in its application to Africans than to the other racial groups, called for a comprehensive ban on European alcohol. ${ }^{59}$

Yet, though apparently less numerous than their opponents, the generally better-educated, more worldly and affluent African advocates of European liquor had gained the political advantage by the mid-1950s. Specifically, the advent of the Federation of Rhodesia and Nyasaland, with its promise of racial equality, at least for the African petty bourgeoisie, emboldened those advocating legalization of European liquor to press their case with greater vigor. Established in 1953, the Federation's principal objective was to insure Southern Rhodesian access to the copper revenues of Northern Rhodesia and the labor supply of Nyasaland ${ }^{\text {to }}$ As a means of mollifying African opposition to the scheme, however, its Southern Rhodesian architects pledged to institute a policy of "racial partnership", or, to use the time-honored phrase so dear to elite Africans, one based on the principle of "equal rights for all civilized men". ${ }^{61}$

It was against this political backdrop, therefore, that in 1956 Stanlake Samkange, son of the anti-liquor Rev. T.D. Samkange (who had died only a few months earlier) and later a leading Zimbabwean historian, declared at the conference of the ruling United Rhodesia Party that "As far as Africans

\footnotetext{
$B M, 26$ May 1956, 1 Sep 1956.

$B M, 23$ July 1956.

$B M, 21$ Apr 1956.

${ }^{59} B M, 29$ Jan 1955, 5 May 1956, 19 May 1956.

(*) Patrick Keatley, The Politics of Partnership (Baltimore, 1963).

o1 With the coming of the Federation, a number of groups were formed to promote racial partnership, chief among which were the Capricorn Africa Society and the Inter-Racial Association of Southern Rhodesia. These groups and individuals associated with them organized a wide variety of multiracial activities, including social events where Africans apparently were served European liquor illicitly. See, for example, Nathan Shamuyarira, Crisis in Rhodesia (London, 1965), especially the chapter entitled "Tea-time Partners".
} 
are concerned [European liquor] is the most important resolution before Congress". Introducing a resolution demanding that Africans "be allowed to purchase European type beers and wines", the younger Samkange warned that future elite African support of the party depended critically on the amendment of the Liquor Law ${ }^{62}$ Having done precious little to fulfill its pledge of racial partnership, this was one issue on which the party could now afford to make some concessions to its African supporters without unduly antagonizing its white electoral base. The congress consequently voted in favor of the resolution.

In the Legislative Assembly, where the government soon introduced legislation to give legal effect to this resolution, opponents of European liquor for Africans, both committed prohibitionists and legislators who thought they knew what was best for Africans, strongly attacked the measure. Using arguments similar to those put forward by the anti-liquor Africans, they declared that most Africans had no desire for European liquor, and that in making such a move the government was "merely pandering to the declared wishes of a vocal minority of Africans who see in this provision some mysterious equality with the European". ${ }^{63}$ Zealous protectors of capital that they were, some legislators worried about the effects of legalization on business. It would, they maintained, lead African workers to develop a taste for the more expensive European beer, thereby leading to demands for wage increases. Others argued that giving Africans the right to drink European liquor would result in a greater incidence of broken homes, abandoned children, malnutrition, automobile accidents caused by drunken Africans and, in a flight of fantasy all too typical of white Rhodesian society, interracial "orgies". ${ }^{64}$

More sober-minded lawmakers, however, agreed that purely "race" legislation was no longer tenable and that the time had come to make special provision for the African petty bourgeoisie on the liquor question. One such legislator

freely admit[ted] that [with] changing times and the evolution of the African, with the emerging of a middle class African today, legislation is extremely difficult to implement if it based merely on race, and it is hardly possible to treat the more civilized emergent African on the same basis as his more primitive brother African. ${ }^{65}$

While the elite African could be counted on to drink responsibly, this

62 Concord, Oct 1956, p. 19.

${ }^{63}$ Debates of the Legislative Assembly (unrevised), 16th May, 1957, vol. 39, no. 36 (Salisbury, 1959), col. 1881.

ot Ibid., cols 1858-1888.

65 lbid., col. 1858. 
argument went, his more "primitive brother" would surely abuse the "privilege". One lawmaker, who also happened to be a physician, expressed this fear in flowery medical terms:

I have no real objection to anyone, white or black, enjoying a glass of wine, but I cannot see the ordinary raw African lingering lovingly over a liqueur. As with his food, so also with his drink, the African is never satisfied until his abdominal tension reaches a certain degree of inflation. One glass of wine or one bottle of beer will never satisfy the ordinary African, and by the time he has drunk to the full, he will have imbibed sufficient alcohol to cause intoxication. ${ }^{66}$

In the end such doubts were overcome and the amendment approved easily. African consumers of European liquor, however, had won only a partial victory. The amended law merely provided for the consumption of light alcoholic beverages, such as beer, wine, ale and stout, and these had to be purchased at specially-designated places. Hard liquor could be obtained only by special permit, and the minister in charge of granting the permits announced that they would be restricted to university graduates and members of the parliament of the Federation of Rhodesia and Nyasaland, which had its capital in Salisbury. ${ }^{67}$

This half-measure nevertheless placed Southern Rhodesia in the ranks of those African colonies that allowed the indigenous population legally to drink some type of European alcohol. In the British East African colonies and Northern Rhodesia, by comparison, this right had been granted in the immediate post-World War II era. There were, perhaps, two reasons for the delay in Southern Rhodesia. First, Southern Rhodesia, unlike the above-mentioned colonies, was not governed directly by the Colonial Office and therefore remained largely unaffected by the "turning point" that took place in British colonial policy in the postwar years. ${ }^{68}$ Rather, a self-governing colony since 1923, Southern Rhodesia enjoyed full control over its domestic affairs. The imperial government retained the right of veto over legislation affecting Africans, but this right was never exercised, despite several requests from Africans to do so.$^{69}$ Second, and more important, the relatively late development of African nationalism in Southern

${ }^{66}$ Ibid., col. 1864.

${ }^{67} B M, 1$ June 1957,16 Nov 1957.

${ }^{68}$ R.D. Pearce, The Turning Point in Africa: British Colonial Policy, 1938-1948 (London, 1982).

${ }^{69}$ Colin Leys, European Politics in Southern Rhodesia (Oxford, 1959); D.J. Murray, The Governmental System in Southern Rhodesia (Oxford, 1970); James A. Chamunorwa Mutambirwa, The Rise of Settler Power in Southern Rhodesia (Zimbabwe), 1898-1923 (Rutherford, N.J., 1980). 
Rhodesia,${ }^{70}$ and the even later black elite participation in it ${ }^{71}$ meant that the quest for European liquor did not become as politically explosive there as it did in neighboring Northern Rhodesia. ${ }^{72}$

Limited though it was, however, the amended Liquor Law, which went into effect in August 1957, caused much excitement among some African consumers of European alcohol. Drinkers in the smaller urban areas, where apparently it had been more difficult to obtain supplies of European liquor, were particularly excited by the novelty of taking their first legal drink. Upon the promulgation of the amended law, reports came from Gwelo (now Gweru) to the effect "that a number of drinkers could be seen carrying six or more bottles [of beer] in the pockets of their trousers and jackets. Some went right through town carrying as many as eight bottles, mainly to try and prove their newly-won drinking freedom." ${ }^{.73}$ In bigger cities like Salisbury and Bulawayo, by contrast, the reaction appears to have been more subdued. The dominant mood among African drinkers in these centers was perhaps summed up aptly by one Salisbury man who explained that "We will not drink more than we have been doing over the past years." 74

Contrary to the predictions of many of those who supported it, however, amendment of the Liquor Law did not lead to the elimination of the illegal shebeen business. On the eve of the amendment the white-owned, Africanoriented Bantu Mirror, which had been urging such a move for over a decade, confidently predicted that the legalization of European liquor would result in a situation where "the skokiaan queens will find themselves without [any] business at all". ${ }^{75}$ Defying such doomsday scenarios, the skokiaan queens and kings continued doing a brisk business long after legalization (and in fact down to the present time).

There were several reasons for this. First, in addition to non-spirituous liquor the shebeens - and the reference here is to the elite shebeens, not the ones that continued selling the traditional brew - served hard liquor, which, as we have seen, Africans could purchase only with a special permit under the amended law. Second, the shebeens sold cold drinks and remained open late into the night, a sharp contrast to the specially-designated bottle stores that catered to Africans, stores that were noteworthy for their lack of refrigeration and limited business hours. Third, and most important, the

7 "Larry W. Bowman, Politics in Rhodesia: White Power in an African State (Cambridge, Mass., 1973); Wellington W. Nyangoni, The Rise of African Nationalism in Zimbabwe (Rhodesia) (Washington, D.C., 1977).

7 West, "African Middle-Class Formation", pp. 377-427.

72 Charles Ambler, "Alcohol, Racial Segregation and Popular Politics in Northern Rhodesia", Journal of African History, 31 (1990), pp. 295-313.

${ }_{73} B M, 17$ Aug 1957.

$74 B, 10$ Aug 1957.

75 BM, 30 Mar 1957 
shebeens offered elite Africans the kind of social exclusiveness that was not available in the beerhalls, the proletarian character of which had now

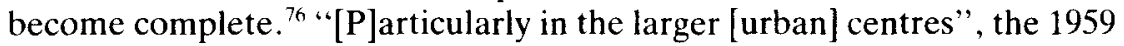
parliamentary report on African drinking habits concluded, "drinking at beer halls was confined to a great extent to the lower classes of natives." On the other hand, it continued, "most of the more advanced, sophisticated natives, in order to avoid mixing with those who frequent the beer halls, prefer to do their drinking at what are now called 'mahobo' parties", that is, shebeens. ${ }^{77}$

Rigidly excluded from the clubs and downtown hotels and restaurants that catered to the white professional and business strata, members of the African petty bourgeoisie saw the elite shebeens as the only alternative social outlet. ${ }^{78}$ As Bulawayo resident Walter Mthimkulu put it: "The lack of public house[s] where Africans can both drink [European liquor] and entertain themselves is by far the most important single reason honouring the success of the shebeens." Of the working-class clientele that dominated the beerhalls, Mthimkulu continued, "one would hardly say they were enjoying themselves. Hour after hour, the boozers sit and talk. Life appears rather boring." In the elite shebeens, by contrast,

There is the spirit of a party which drinkers enjoy very much. The patronisers are jolly, swinging their bodies and of course taking their sip too. Admittedly they pay more for the stuff, but it is worth the extra, and any observer without prejudice will verify this statement. ${ }^{79}$

More scientific observers also verify that there was a close correlation between the consumption of European liquor and income, one of the main determinants of elite status. Surveys of African consumption habits in

${ }^{76}$ BM. 23 Mar 1957. 30 Mar 1957, 18 Jan 1958, 7 Jan 1961, 8 Apr 1961.

7 Second Report of the Select Committee on Supply of Liquor to Non-Europeans, p. 7. See also Walcott, The African Beer Gardens of Bulawayo, p. 188, who, on the basis of research done in the early 1970s, asserts that "certain members of the [Bulawayo African] township community who were especially visible as unique personalities or because of formal roles they occupied were conspicuous by their absence from beergarden life. Perhaps beer-garden clientele includes individuals from all strata of township dwellers, but essentially the facilities catered to lower-class urbanites."

${ }^{78}$ Founded in Salisbury in 1958, the Capital Club, an establishment aimed at providing "facilities [for dining, reading, lectures and entertainment] which can be used by all races". was the only white-run club that accepted African members. However, only a small number of well-connected elite Africans in Salisbury belonged to this club, which did not serve alcohol of any kind, since its founding members included such staunch anti-liquor stalwarts as the Rev. Kachidza. See NAZ, H15/24/18: The Capital Club. Aug 1958; The Capital Club: Memorandum to Members, 22 Oct 1958.

${ }^{74} B M, 7 \mathrm{Jan}$ 1961. For a brief discussion of elite shebeens in a Salisbury African township in the early 1970s, see Joan May, Drinking in a Rhodesian African Township (Salisbury. 1973).p. 66. 
Salisbury and Umtali in 1963-1964 demonstrated that the higher the income the greater the amount spent on liquor in general and European liquor in particular. "African type beer accounted for most expenditure [on liquor] in the first three quintiles but, in the upper two quintiles more was spent on European type beer", the Salisbury report concluded. ${ }^{80}$ In Umtali, the wealthiest twenty percent of the families surveyed reported spending an average of seven shillings and six pence per month on European beer. For the average family in the poorest twenty percent, by contrast, monthly expenditure on this type of alcohol amounted to only four pence. ${ }^{81}$ Thus the consumption of European alcohol, whether legally or illegally, was an important distinguishing feature of the African elite in Southern Rhodesia.

This is not to suggest that non-elite Africans did not drink or desire this kind of alcohol. In the excitement surrounding the unbanning of nonspirituous liquor in 1957, the sale of wine in the beerhalls became quite brisk. With the falling off of the "initial flush of enthusiasm", however, the consumption of wine among beerhall patrons decreased dramatically, evidently for financial reasons. ${ }^{82}$ Similarly, a survey in the late 1960 s of African drinking patterns in one Salisbury township found that most drinkers preferred European liquor, even if they could not afford it; and that consumption of this kind of liquor tended to increase with income. ${ }^{83}$ Whether for reason of habit, status, or purchasing power, therefore, elite Africans were actually much more likely to drink European liquor than Africans of other social strata.

Even though they had been given unimpeded access to light alcoholic beverages under the amended Liquor Act of 1957, Africans who drank hard liquor without a permit remained liable to criminal prosecution. Permit holders, who nearly two years after the amendment numbered only between twenty-five and thirty, were entitled to purchase spirits, but it was an offence for them to pass it along to those who had no permit. ${ }^{84}$ Like strict prohibition itself, however, this restriction was routinely violated. Joshua Nkomo, a confirmed teetotaler and current Vice President of Zimbabwe, recalls that while he personally had opposed the partial lifting of the liquor prohibition, once it became an accomplished fact "some of my colleagues did persuade me to take out a permit and pass my supply on to them!" 85

However, in a final victory for the advocates of European alcohol, the

*1) Report on Urban African Budget Survey in Salisbury, 1963/64 (Salisbury, 1965), p. 15.

${ }^{8}$ Report on the Urban African Budget Survey in Umtali, 1963 (Salisbury, 1965), p. 22.

8. Debates of the Legislative Assembly (unrevised), 17th April, 1959, no. 57 (Salisbury, 1959), col. 3219.

4.3 R.D. Reader and Joan May, Drinking Patterns in Rhodesia: Highfield African Township, Salisbury (Salisbury, 1971).

*1 Debates of the Legislative Assembly (unrevised), 23rd April, 1959, no. 60 (Salisbury, 1959), col. 3438 .

${ }^{85}$ [Joshua] Nkomo. The Story of My Life (London, 1984), p. 96. 
permit system was also abolished in late 1961, when the Liquor Act was amended to eliminate all racial restrictions in the purchasing and consumption of European liquor. According to the Chief Native Commissioner, the interlude between the legalization of non-spirituous and spirituous liquors was the government's way of "allow[ing] a little time for a widespread responsible leadership to emerge in the drinking of hard spirits which could pass on experience and guidance to the masses for whom it was a novelty" ${ }^{86}$ This might well have been so, but by 1961 liquor had also become something of a non-issue, having been superceded by political questions of far greater importance.

This was, of course, a very recent development. As late as 1959 a debate in the Legislative Assembly on whether the permit system should be abolished and Africans given unrestricted access to hard liquor - as would soon be done in the case of Asians and coloureds - had generated heated discussion, with the weight of opinion decidely against the idea ${ }^{87}$ Some two and a half years later, as part of a larger effort to remove the most irritating aspects of racial discrimination, a repeal bill was actually introduced into the legislature. By now, however, the opposition had largely disappeared, leaving only a small number of diehards to rail against this latest act of "appeasement" to Africans whose demands knew no end. ${ }^{88}$

The reason for this about-face was the transformation that had taken place in elite African political consciousness. As late as 1957, as has been shown in the case of the liquor prohibition, which was partially lifted in that year, elite Africans were still hopeful of gaining full citizenship rights through adherence to the racial partnership philosophy ushered in by the Federation. Within three years, however, a series of events had combined to negate these hopes, leaving in their wake broken promises and shattered dreams. ${ }^{89}$ Their drive for upward social mobility thus frustrated, elite Africans turned to nationalism, that is, the demand for black majority rule, to realize their aspirations. With their political legitimacy and right to govern now openly rejected, liquor became a side issue for both the white rulers and their elite African challengers. Indeed, some whites might well have come to favor the legalization of spirits in the hope that the African nationalists would drink themselves into a permanent stupor.

But if in the end the definitive removal of the prohibition of European liquor proved anti-climactic, the decades-long struggle that preceded it was an important crucible in the creation of a vital segment of the African elite.

* Report of the Secretary for Native Affairs and Chief Native Commissioner for the Year Ended 1961 (Salisbury, 1962), p. 5.

${ }^{87}$ Debates of the Legislative Assembly, 23rd-24th April. 1959, cols 3430-3492.

* Debates of the Legislative Assembly (unrevised), 16th November, 1961, no. 3, vol. 49 [sic] (Salisbury, 1961), cols 108-125.

*9 West, "African Middle-Class Formation", pp. 408-427. 
There were, to be sure, other crucibles in the process of African petty bourgeois formation, including the struggles for increased educational opportunities, for maintenance of the qualified franchise, for "improved" housing, for freehold property rights (both the rural and urban areas), for the right of aspiring capitalists to operate in the central business districts, and generally for the advent of a sociopolitical regime in which careers would be open to talent on a non-racial basis. ${ }^{90}$ These, however, were objectives on which virtually all elite Africans agreed. The quest for legal access to European liquor, by contrast, was more symbolically important, both for elite Africans and white settlers, and it certainly generated more controversy within elite African circles. ${ }^{91}$ It also helped to sharpen political skills that would later become extremely valuable. A number of individuals who were closely identified with the European liquor issue went on to assume important positions in the nationalist movement that eventually led Zimbabwe to independence in $1980 .{ }^{92}$

*) Ibid.; Volker Wild, "Black Competition or White Resentment?: African Retailers in Salisbury, 1935-1953", Journal of Southern African Studies, 17 (1991), pp. 177-190.

"From an historical point of view, ethnicity ("tribalism") and lobola (bridewealth) are perhaps the only other issues that were more internally divisive among the African petty bourgeoisie. On the ethnic and lobola issues, see Ian Phimister and Charles van Onselen, "The Political Economy of Tribal Animosity: A Case Study of the 1929 Bulawayo Location 'Faction Fight' ", Journal of Southern African Studies, 6 (1979), pp. 1-43; Terence Ranger, "Missionaries, Migrants and the Manyika: The Invention of Ethnicity in Zimbabwe", in Leroy Vail (ed.). The Creation of Tribalism in Southern Africa (Berkeley and Los Angeles, 1989), pp. 118-150; and West, "African Middle-Class Formation", pp. 111-121, 465-486.

92. This list includes, though it is by no means limited to, the current Foreign Minister, Nathan Shamuyarira, who strongly supported Stanlake Samkange's motion at the 1956 United Rhodesia Party congress; Leopold Takawira, who until the end of 1960 was executive officer of the Capricorn Africa Society and who, as a political prisoner in Ian Smith's Rhodesia, died a cruel death in 1970; and the first African advocate in Southern Rhodesia, Herbert Chitepo, who died in Zambia in 1974 under circumstances that an official Zambian commission attributed to inter-ethnic rivalry within his wing of the nationalist movement. 